\title{
Characterising Spanish retirees enrolled in university programs: four differentiated profiles
}

\author{
Yolanda López-Ramos, \\ Esperanza Navarro-Pardo, \\ Juan José Fernández Muñoz \\ \& Ricardo Pocinho
}

\begin{abstract}
Due to age discrimination, retirees are usually viewed as a homogeneous group and therefore are all treated in the same way by society. In-depth research into the differences between the individuals in this age group gives us the opportunity to discover if all retirees deal with this change in the same manner. The objective of our study is to identify different profiles in a sample of Spanish retirees enrolled in university programs according to different factors. 991 Spanish retirees were evaluated both in terms of continuous variables, such as organizational pressures, health problems, interest in retirement, levels of work-related stress, social support and resilience, and demographic variables. A cluster analysis was performed which enables the definition of groups with homogeneous characteristics within large samples. The variables were included in each of the clusters using Student's t-test for the continuous variables and a chi squared test for the categorical variables. The results of the analysis confirm the existence of four groups or clusters based on the variables used in the research. The differentiation of profiles for retirees helps to eliminate social discrimination motived by age and mistaken beliefs about retirees (ageism) and assists in the adjustment and personalization of retirement preparation programs.
\end{abstract}

Keywords:

retirement; resilience; social support; satisfaction; cluster analysis. 


\title{
Caraterização dos reformados espanhóis envolvidos em programas universitários: quatro perfis diferenciados
}

\begin{abstract}
Resumo: Devido à discriminação de idade, os aposentados são geralmente vistos como um grupo homogéneo, e são, portanto, todos tratados da mesma maneira pela sociedade. O aprofundamento da investigação sobre as diferenças entre os indivíduos nesta faixa etária dá-nos a oportunidade de descobrir, se todos os aposentados lidam com esta mudança da mesma maneira. O objetivo do nosso estudo é identificar os diferentes perfis numa amostra de aposentados espanhóis, inscritos em programas universitários de acordo com diferentes fatores. Foram avaliados 991 reformados espanhóis em termos de variáveis contínuas, tais como, pressões organizacionais, problemas de saúde, interesse na reforma, níveis de stress relacionados com trabalho, apoio social e resiliência, e variáveis demográficas. A análise de cluster que foi realizada permite a definição de grupos com características homogéneas dentro de grandes amostras. As variáveis foram incluídas em cada um dos grupos utilizando o teste $t$ de Student para as variáveis contínuas e teste qui-quadrado para as variáveis categóricas. Os resultados da análise confirmam a existência de quatro grupos ou agregados a partir das variáveis utilizadas na pesquisa. A diferenciação dos perfis para reformados ajuda a eliminar a discriminação social motivada pela idade e crenças equivocadas sobre os reformados (idadaísmo) e auxilia no ajuste e personalização de programas de preparação para a reforma.
\end{abstract} Palavras-chave: reforma; resiliência; apoio social; satisfação; análise de agrupamento.

\section{Caractérisation des retraités espagnols inscrits aux programmes universitaires: quatre profils différenciés}

Resumé: En raison de la discrimination fondée sur l'âge, les retraités sont habituellement considérés comme un groupe homogène et sont donc tous traités de la même manière par la société. Une recherche approfondie sur les différences entre les individus de ce groupe d'âge nous donne l'occasion de découvrir si tous les retraités s'occupent de ce changement de la même manière. L'objectif de notre étude est d'identifier différents profils dans un échantillon de retraités espagnols inscrits dans des programmes universitaires selon différents facteurs. 991 retraités espagnols ont été évalués à la fois en termes de variables continues, telles que les pressions organisationnelles, les problèmes de santé, l'intérêt pour la retraite, les niveaux de stress lié au travail, le soutien social et la résilience et les variables démographiques. Une analyse par grappes a été effectuée qui permet de définir des groupes présentant des caractéristiques homogènes dans de grands échantillons. Les variables ont été incluses dans chacun des grappes en utilisant le test t de Student pour les variables continues et un test chi carré pour les variables catégoriques. Les résultats de l'analyse confirment l'existence de quatre groupes ou clusters en fonction des variables utilisées dans la recherche. La différenciation des profils pour les retraités contribue à éliminer la discrimination sociale motivée par l'âge et les croyances erronées à propos des retraités (ageism) et aide à l'ajustement et à la personnalisation des programmes de préparation à la retraite.

Mots-clés: retraite; résistance; aide sociale; la satisfaction; l'analyse par clusters

\section{Caracterización de jubilados españoles inscritos en programas universitarios: cuatro perfiles diferenciados}

Resumen: Debido a la discriminación por edad, los jubilados suelen ser vistos como un colectivo homogéneo y por lo tanto son tratados de la misma forma por la sociedad. La investigación en profundidad sobre las diferencias entre los individuos de este grupo de edad, nos da la oportunidad de descubrir si todos los jubilados afrontan este cambio de la misma manera. El objetivo de nuestro estudio es identificar los diferentes perfiles existentes en una muestra de jubilados españoles matriculados en los programas universitarios, de acuerdo a diferentes factores. 991 jubilados españoles fueron evaluados en relación a variables continuas, como las presiones organizacionales, problemas de salud, interés por la jubilación, niveles de estrés relacionado con el trabajo, el apoyo social y la capacidad de recuperación, y las variables demográficas. Se realizó un análisis de conglomerados que permite la definición de grupos con características homogéneas en muestras grandes. Las variables fueron incluidas en cada uno de los grupos utilizando la prueba T de Student para las variables continuas y la prueba de Chi cuadrado para las variables categóricas. Los resultados del análisis confirman la existencia de cuatro grupos o conglomerados basados en las variables utilizadas en la investigación. La diferenciación de los perfiles de personas jubiladas ayuda a eliminar la discriminación social por edad y las creencias erróneas acerca de los jubilados (Edadismo) y ayuda en la adaptación y personalización de los programas de preparación para la jubilación.

Palabras Clave: jubilación; resiliencia; apoyo social; satisfacción; análisis de conglomerados 


\section{Introduction}

The aging of the Spanish population is a phenomenon, which merits special attention; the aging rate, according to the latest available statistics from the National Statistics Institute of Spain (Instituto Nacional de Estadística, INE) for 2014 is 18.1\% of the total population $(46,771,341$ people). Consequently there is a pressing interest to study the needs of the elderly and ways to improve their quality of life. One would expect such a large group of people to be heterogeneous, but we know that those in this phase of life suffer greater discrimination than those in other life stages (ageism). As a result, research which helps to eliminate the stereotype which categorizes older people as a single body, merging their characteristics and needs, is vital. Numerous studies have measured the impact that negative age stereotypes have on health. In this area, a longitudinal study carried out in Ohio with a sample of 433 participants aged 50 and over suggested the way in which individuals view their own aging affects their functional health (Levy, Slade \& Kasl, 2002).

Aging is a multidimensional process, which involves diverse changes in the various ways people function over time. These changes affect biological, psychological and social processes (Kanfer \& Ackerman, 2004).

On the one hand, both age and aging itself can be defined as a result of different continuous dimensions such as individual, social and environmental characteristics and viewpoints (Van der Heijden, Schalk \& Van Veldhoven, 2008). Accordingly, as a collective, older adult workers disassociated from their occupational activity could constitute a heterogeneous group of people. On the other hand, previous research suggests the retirement experience is one of the most important and consequential changes in this life stage (Van der Heijden, Schalk \& Van Veldhoven, 2008). Diversity, both among the workers and in their retirement experiences, means it is advantageous to study groups or types of retirees based on common factors, principally those related to the way they left employment and their subsequent adaptation to retirement, as well as their sociodemographic characteristics (Van Droogenbroeck \& Spruyt, 2014).

\section{Retirement theories}

Several studies have identified different variables and theoretical models to describe occupational retirement, both early retirement and that which occurs at ordinary retirement age (Wang, 2007). With regard to theoretical models, some studies have used Beehr's model (1986) of retirement behavior, which distinguishes between the personal and environmental factors that influence the decision to retire. Other authors have used role theory and applied continuity theory to study the transition and adjustment from working life to retirement (Atchley, 1989). More recently, other 
researchers (Kanfer \& Ackerman, 2004) have used motivation theory in the analysis of the factors, which drive workers to stay in or abandon the workforce. However, due to the highly dynamic nature of this field of research, subject as it is to the economic and socio-occupational factors which surround the processes of retirement, there is no single model or conceptual framework which integrates all these elements and guides research.

\section{Antecedent and consequent variables involved in the retirement process and adaptation to retirement.}

First among antecedent variables and particularly notable are health problems, either experienced by the worker themselves or a member of their family; such health problems can create a negative situation which facilitates the worker's early retirement (Van Droogenbroeck \& Spruyt, 2014).

Secondly, there are variables related to the low psychosocial quality of work. Monotonous jobs, repetitive tasks, negative experiences of the work environment, and the physical and psychological demands the job places on a person can push the employee to end their working life (Principi \& Fabbietti, 2015). Lund and Villadsen (2005) identified numerous factors related to work, which drove older workers to retire early; specifically, performing a job which is very physically-demanding, repetitive, requiring continuous effort and involving high levels of work-related stress. The study of Solem et al. (2014) demonstrated that working conditions are a highly important factor in the decision to retire. These authors found that one of the most important reasons why workers in the mining sector accepted retirement was that it meant they could leave a hard, unhealthy and dangerous job. Human resources practices designed to increase productivity, which involve policies of pressuring workers into retirement are also a trigger factor in retirement decisions (Dorn \& Sousa Poza, 2005; Solem et al., 2014).

Thirdly, numerous studies have identified a high level of involuntariness in retirement decisions, where companies exercise organizational pressure on workers (Dorn \& Sousa Poza, 2005). Van Solinge and Henkens (2007) suggested that restrictive conditions, understood as strategies to exert pressure on the worker, limit the opportunities for older workers to remain within the organization. According to this line of thought, organizations can transform a cooperative workplace into a hostile environment and make changes to posts and tasks to force the worker into an involuntary acceptance of an offer of early retirement (Dorn \& Sousa Poza, 2005). In fact, in many cases, an offer of early retirement is unexpected and the decision-making period is very brief so a worker has to adapt quickly to the changes they will experience as a result of leaving the workforce. 
Finally, in terms of personal variables, the worker's coping style and, more specifically, their resilience in response to new conditions has been identified as a factor, which has positive effects on subsequent adaptation to retirement (Moret et al., 2015).

With regard to the consequent variables or factors involved in adaptation to retirement, studies such as those by Potocnik, Tordera and Peiró (2010) have identified the positive effects which different activities (bridge jobs as part of the transition to full retirement, volunteering, hobbies and personal interests, etc.) can have on the adaptation to post-work life. On the other hand, there are various factors which have been repeatedly identified as influential on adaptation to retirement, such as the financial situation of the retiree during retirement, their level of educational attainment (Van Solinge \& Henkens, 2014), socialization and social support levels, personality traits, the retiree's ability to adapt, coping strategies used and participation in preventative intervention programs (Gómez \& Martí, 2003).

Several of these factors are resilience to change, social support on elderly and the level of satisfaction during the post-working life (Ong, Bergeman, Bisconti \& Wallace, 2006).

A study with Spanish retirees over 60 years old identified a significant relationship between perceived social support and satisfaction with life, although there was not a significant relationship with sociodemographic variables (Cadenas-Salazar, VillarrealRíos, Vargas-Daza, Martínez-González \& Galicia-Rodríguez, 2009). Several studies underline the positive effect from social networks on stressful facts (Gore, 1978; Guarino \& Sojo, 2011).

With the aforementioned antecedents in mind, the main objective of this study is to identify possible groups or profiles in a broad sample of Spanish retirees (early and ordinary) according to the way they left employment, their subsequent adaptation to retirement, the presence of resilient coping and their sociodemographic characteristics. This study is an attempt to examine, classify and group the data obtained from research using a large sample. The psychosocial and employment profiles which best match the characteristics of the sample will be defined using the cluster sampling technique to identify possible natural groupings. This classification may help to systematize the wide variety of experiences of the retirement transition and post-work adjustment, a phenomenon, which currently affects a heterogeneous body of workers, and to profile more accurately the diverse life experiences which may be included in the traditional image of retirement, which is generally viewed as a homogeneous process. The identification of different groups or profiles among retirees, taking into account variables related to the decision to retire and the workforce exit process, as well as satisfaction levels in the stages after retirement, is a topical issue in current retirement research because it aims to shed light on the particularities of a process which does not seem to constitute a uniform transition (Wang, 2007). 


\section{Data collection}

\section{Participants}

The sample used consisted of 991 retirees (early and ordinary) from all over Spain, $75.9 \%$ of whom were male and $24.1 \%$ female. The mean age was 62.7 years and the standard deviation \pm 5.89 , with an age range of 50 to $85.11 .9 \%$ of the retirees had no formal education; $31.6 \%$ completed primary education; $32.9 \%$ completed secondary education studies and $18.2 \%$ had university qualifications. $56.7 \%$ were married, $10 \%$ were single; $5.2 \%$ were widowed and $2.4 \%$ were divorced. With regard to the participants' occupational category: $7.6 \%$ were senior managers, $6.5 \%$ were middle managers, $14.7 \%$ were technicians, $15.2 \%$ were administrative workers, 25\% were skilled workers and $11 \%$ were unskilled workers. Finally, with regard to the occupational sector: $32.2 \%$ worked in the public sector, while $43.2 \%$ worked in the private sector. The missing values were excluded from the frequency analyses of the aforementioned sociodemographic variables.

\section{Method}

Incidental sampling was used. The seniors were enrolled in university programs for older people at different Spanish universities (Alicante, Valencia, Basque Country and Madrid). Prior to the final preparation of the questionnaire, a pilot selection of 60 people was carried out, the responses were reviewed to test the coding and the meaning of the items translated from the original instrument. The questionnaire was self-administered during one of the classes, under the supervision of trained psychologists and with permission from both the university and the teacher responsible for the class. Participants were volunteers and completed the necessary informed consent documentation.

\section{Instruments}

Retirement Satisfaction Inventory (RSI). The inventory, developed by Floyd et al. (1992), aims to measure reasons for retirement, satisfaction with life in retirement and sources of enjoyment. This study used the version of the inventory adapted to Spanish by Fernández, Crego and Alcover (2011), whose psychometric properties were similar to those of the original. In this regard, three subscales were identified. The first was reasons for retirement $(a=.71)$, comprised of four factors: personal interest in retirement $(a=.73)$; retirement due to health problems $(a=.90)$, work-related stress $(a=$ $.65)$, and organizational pressures $(a=.48)$. Those surveyed responded using a seven point Likert-type scale where one $=$ not at all important and seven = very important. The second subscale was satisfaction with life in retirement, comprised of two factors: satisfaction with personal and family matters $(a=.71)$ and satisfaction with matters 
related to activities, accessibility and resources $(a=.75)$; once again, the response scale was a Likert-type seven point rating system where one $=$ extremely dissatisfied and seven = extremely satisfied. The third and final scale was sources of enjoyment (a $=.75)$, comprised of three factors: freedom and control $(a=.79)$, stress reduction $(a=$ .83 ) and social activities $(a=.64)$. The response scale was a five-point Likert-type scale where one $=$ not at all important and five $=$ very important.

Brief Resilient Coping Scale (BRCS). This scale developed by Sinclair and Wallston (2004) measures optimism, perseverance, creativity and positive growth when faced with adverse situations. The original scale was comprised of four items and a single factor. The BRCS is a tool to measure resilience, which has demonstrated adequate levels of reliability and validity. This study used a version of the scale adapted to Spanish by Moret et al. (2015) which has excellent psychometric properties $(a=.86)$ and whose items have factorial weights in a range of .73-.88. The response scale is a fivepoint Likert-type scale where one $=$ does not describe me at all and six $=$ describes me very well.

Multidimensional Scale of Perceived Social Support (Zimet, Dahlem, Zimet \& Farley, 1988). This scale includes 12 items which measure the perception of social support received from three sources: family, friends, and significant others. The internal consistency index of the original scale developed by Zimet et al. (1998) was a = .93. The three factors demonstrated the following internal consistency coefficients: perceived social support from significant others $(a=.93)$, perceived social support from family $(a=.92)$ and from friends $(a=.94)$. The response scale is a seven-point Likert-type scale with seven anchor points, where one = very strongly disagree and seven = very strongly agree.

\section{Data Analysis}

We performed a cluster analysis in two phases (two-step cluster) using the SPSS version 22.0 to determine the number of clusters in a large data set. This cluster analysis allows the simultaneous processing of categorical (sociodemographic variables) and continuous variables (RSI, BRCS and MSPS and its subscales). In this study we have used the log likelihood function, meaning that continuous variables have a normal distribution and categorical variables have a multinomial distribution. The inclusion of each continuous variable in the relative group is based on the t-statistics method. A negative or positive significance value of the statistic leads to a value of the variable lower or higher than the cluster mean.

On the other hand the groups of categorical variables are determined using the chisquared test. This is an exploration and classification technique used to determine the most appropriate number of clusters in a large sample of participants. 


\section{Results}

Results from the cluster analysis are presented as well as the frequency distributions and descriptive statistics for the variables included in the statistical procedure. Table 1 presents typical deviations and the range of responses for the continuous variables included in the cluster analysis.

Table 1. Means and standard deviations for continuous variables analyzed in the research

\begin{tabular}{lccc}
\hline & $\begin{array}{c}\mathrm{N} \\
\text { in }\end{array}$ & Max & $\begin{array}{r}\text { Mea } \\
\mathrm{n}\end{array}$ \\
\hline Resilience & 1 & 4 & 2.95 \\
\hline Health problems & 1 & 7 & 2.71 \\
\hline Personal interest in retirement & 1 & 7 & 2.91 \\
\hline Organizational pressures & 1 & 7 & 2.97 \\
\hline Work-related stress & 1 & 7 & 2.66 \\
\hline Perceived social support from significant others & 1 & 7 & 5.43 \\
\hline Perceived social support from family & 1 & 7 & 5.35 \\
\hline Perceived social support from friends & 1 & 7 & 4.83 \\
\hline Satisfaction with family matters & 1 & 5 & 3.70 \\
\hline Satisfaction with resources & 1 & 5 & 3.80 \\
\hline
\end{tabular}

$N=991$

The results from the cluster analysis demonstrate the existence of four clusters. The first cluster comprises $17.6 \%$ of the valid data; the second is comprised of $26.1 \%$ of the valid cases; the third is made up of $23.5 \%$ of the valid cases; and the fourth is comprised of $32.8 \%$ of the total valid cases. $39.4 \%$ of the total participants were excluded from the cluster analysis because when the log-likelihood test criteria were applied they were not allocated to any of the four clusters identified. Table two includes a summary of the percentage distribution for each of the resulting clusters. 
Table 2. Optimal cluster distribution for retiree's sample

\begin{tabular}{|c|c|c|c|c|}
\hline & & $\mathrm{N}$ & $\begin{array}{r}\% \text { of } \\
\text { Combine }\end{array}$ & $\begin{array}{l}\% \text { of } \\
\text { Total }\end{array}$ \\
\hline \multirow[t]{5}{*}{ Clusters } & 1 & 106 & $17.6 \%$ & $10.7 \%$ \\
\hline & 2 & 157 & $26.1 \%$ & $15.8 \%$ \\
\hline & 3 & 141 & $23.5 \%$ & $14.2 \%$ \\
\hline & 4 & 197 & $32.8 \%$ & $19.9 \%$ \\
\hline & Combine & 601 & $100.0 \%$ & $60.6 \%$ \\
\hline Excluded cases & & 390 & & $39.4 \%$ \\
\hline Total & & 991 & & $100.0 \%$ \\
\hline
\end{tabular}

\section{Cluster one}

The continuous and significant variables, which form part of the first cluster are organizational pressures $(M=3.50, D T=1.24)$ and health problems $(M=2.96, D T=1.57)$. In terms of the categorical variables, which characterize this first cluster, levels of educational attainment and profession have been identified. With regard to level of educational attainment, this cluster contains $94.3 \%$ of all the retirees without any formal education, $2.3 \%$ of those who have a primary level education, and $26.2 \%$ of all those who have university qualifications.

Figure 1. Significant and continuous variables which form part of the first cluster

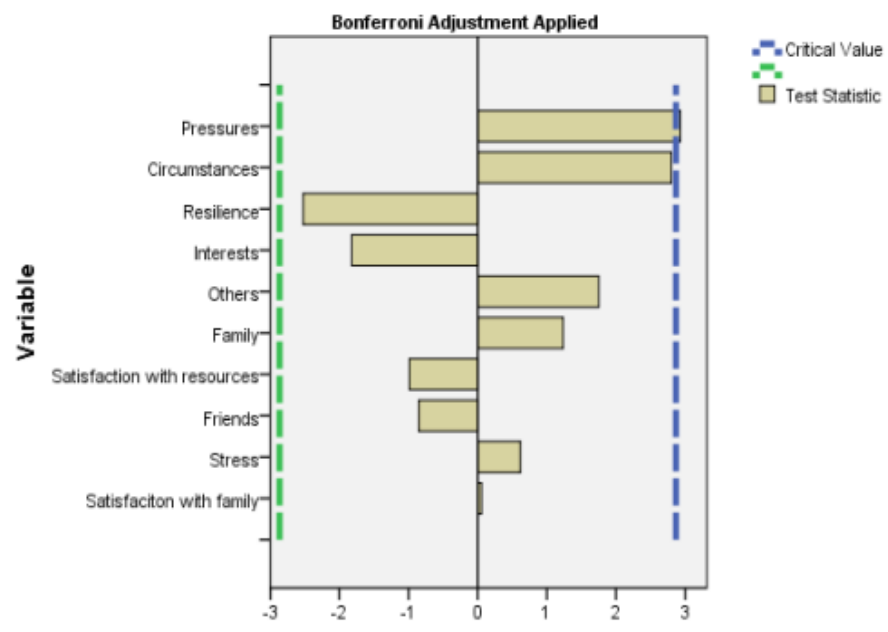




\section{Cluster two}

The continuous variables, which form part of cluster 2 are interest in retirement (M $=2.55$, DT $=1.20)$, work-related stress $(M=2.33, \mathrm{DT}=1.23)$ with a negative sign and organizational pressures $(M=3.62$, $D T=1.14)$, and resilience $(M=3.33$, $D T=3.88)$ with a positive sign. Figure 2 illustrates the continuous variables, which comprise this second cluster.

Figure 2. Significant and continuous variables which form part of the second cluster

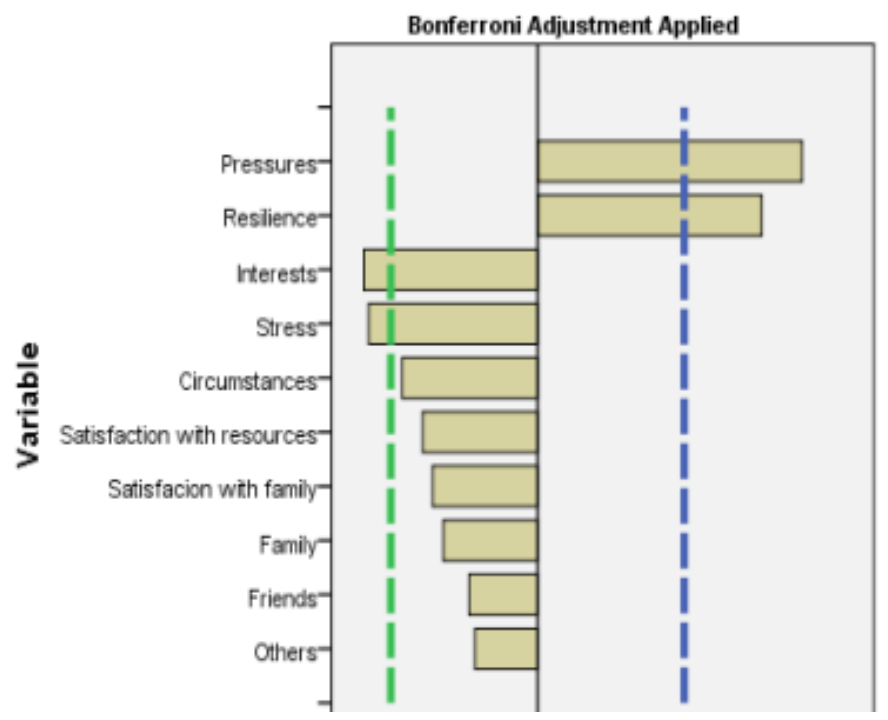

The categorical variables, which form part of this second cluster are occupational sector, occupation and marital status. $67.1 \%$ of all the retirees form part of this cluster, being the most common profile in our sample. With regard to the distribution of the retirees according to occupational sector, all the retirees in this cluster worked in the private sector; the public sector is unrepresented. This cluster contains $38.9 \%$ of all the skilled workers and $37.6 \%$ of all the unskilled workers. Finally, in terms of marital status, $30.6 \%$ of all single retirees form part of this second cluster, $1.9 \%$ of all the married retirees, $8.3 \%$ of all the widowed retirees and $6.75 \%$ of all the divorced retirees. This cluster contains $15.8 \%$ of all the retirees in the sample. 


\section{Cluster three}

The continuous variables, which form part of the third cluster are organizational pressures with a negative sign $(M=2.60$, DT $=1.35)$, perceived social support from friends $(M=5.06, D T=1.51)$ and interest in retirement $(M=3.24$, $D T=1.47)$ with a positive sign.

Figure 3. Significant and continuous variables which form part of the third cluster

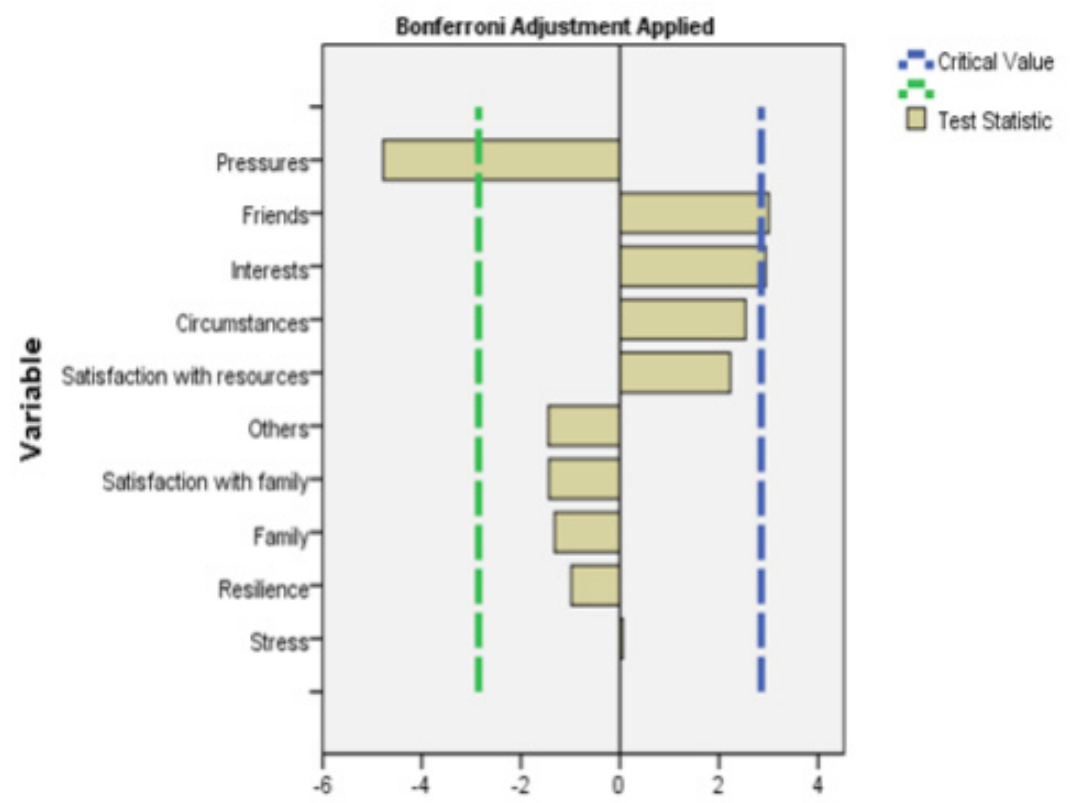

The categorical variables which form part of the third cluster are: gender, with $82.9 \%$ of all the female retirees and $9.1 \%$ of all the male retirees forming part of the cluster, $8 \%$ were missing cases; marital status, with $19.5 \%$ of all the single retirees and $98.1 \%$ of all the married retirees forming part of this cluster; and, finally, level of educational attainment. It is worth noting that, in regard to this final variable; a hundred percent of all the retirees with university qualifications form part of this cluster, $20 \%$ of all retirees with secondary school education and $27.1 \%$ of the retirees with a primary education.

\section{Cluster four}

The continuous variables, which form part of the fourth cluster are retirement due to health problems with a negative sign $(M=2.30, D T=1.12)$ and satisfaction with family matters with a positive sign $(M=4.58, D T=3.93)$. 
Figure 4. Significant and continuous variables which form part of the fourth cluster

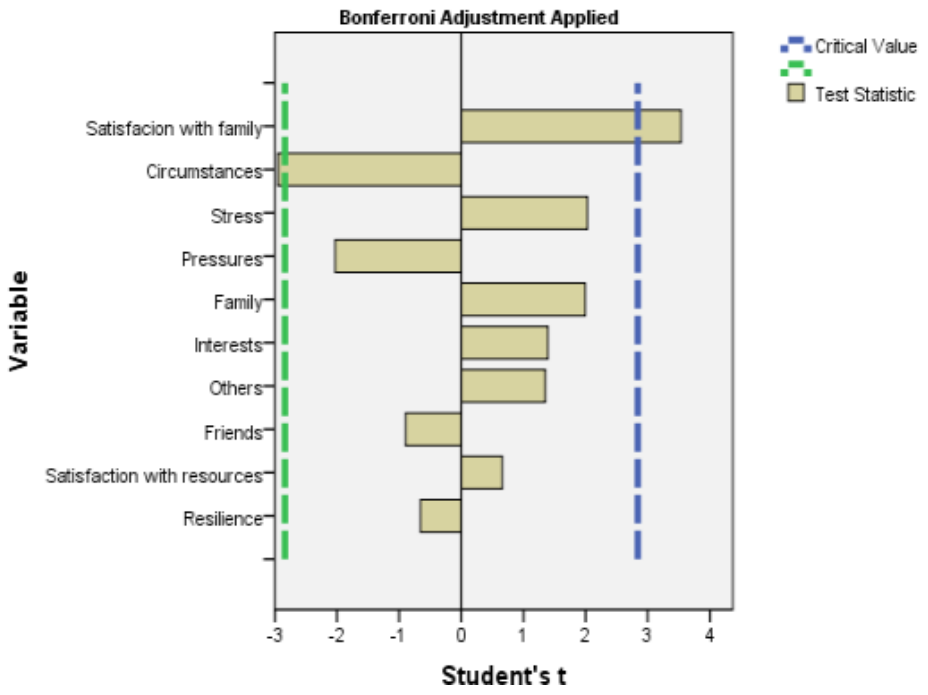

Finally, the categorical variables which form part of cluster four are: occupational sector, with $53.7 \%$ of the retirees who had worked in the public sector forming part of this cluster and no retirees who had worked in the private sector; marital status, with $38.5 \%$ of all the single retirees and $26.5 \%$ of all the divorced retirees forming part of this cluster; and level of educational attainment, with $49.6 \%$ of all the retirees with primary level studies and $32.9 \%$ of all the retirees with secondary school studies forming part of this cluster.

\section{Discussion}

The aim of this study was to identify possible groups of retirees with common traits in terms of sociodemographic features, characteristics of the retirement process, perceived social support and resilience. The results obtained confirm the existence of four groups or profiles which are different from one another but which present internal homogeneity in terms of the variables included in the model (Fernández, Alcover \& Crego, 2013). We may label these four groups as involuntary retirees, non-voluntary retirees with high resilience, voluntary with high education and high perceived social support from friends and finally voluntary retirees with low level of education and high satisfaction with their family (Fernández, Crego \& Alcover, 2013).

The first cluster or involuntary retirees is distinguished by workers who experienced organizational pressure to abandon work, who had health problems during the retire- 
ment process and who, for the most part, have no formal education. These results are in line with those from several studies, which have identified working conditions and health problems as the variables which have the greatest impact on the retirement decision-making process (Fernández, Alcover \& Crego, 2013)

In the second cluster, non-voluntary retirees with high resilience are retirees with little interest in leaving the workforce, low levels of stress and who experienced organizational pressure to retire but showed high resilience during the process. The majority was former private sector workers with primary and secondary education and who are, mostly, single. In this case also, the low level of interest in leaving the workforce and organizational pressure are the variables, which define the worker's decision-making process (Dorn \& Sousa-Poza, 2005). Lund and Villadsen (2005) suggested that older workers consider their health, organizational pressure and work-related stress levels to be the most important variables when it comes to explaining their decision to leave the workforce. It seems these workers, given their high resilience, do not want to accept early retirement at first but have to accept the offer eventually. In the same vein, some studies (Dorn \& Sousa-Poza, 2005) indicate that these workers have been forced into the retirement decision voluntarily given that, initially, they showed resistance to leaving employment but finally resigned due to the limited possibility of rejecting the offer.

In the first two clusters, we might observe the existence of an involuntary decisionmaking process, explained by a low interest in leaving employment, strong organizational pressures and health problems (Gómez \& Martí, 2003). Everyday work experiences lead to a perceived decline in the quality of working life which, from a psychological perspective, requires us to contextualize these processes within a specific organization, under specific working conditions and for specific groups of workers, all framed in a specific socio-economic context (Van Solinge \& Henkens, 2007).

The third cluster contains workers who did not experience organizational pressures, voluntary with high education and high perceived social support from friends who had personal interest in leaving the workforce and who, during the retirement process, had the social support of friends. Principally, this cluster is composed of married women with university qualifications. In accordance with the literature, this group of retirees made a voluntary decision to leave the workforce (Dorn \& Sousa-Poza, 2005; Solem et al., 2014; Van Solange \& Henkens, 2014).

Finally, voluntary retirees with low level of education and high satisfaction with their family the fourth cluster is characterized by the inclusion of workers without health problems who, during this new phase in their lives, experience a high level of satisfaction with life and retirement; the majority worked in the public sector and is single or divorced. Like the third cluster, these are workers who, as a result of being in good health, believe retirement will be satisfying in comparison to their current situation and decide to accept the retirement offer voluntarily (Solem et al., 2014). 
As observed in this paper, various studies have identified two typologies of retirees according to the nature of their decision to leave work: those who made the decision to retire voluntarily and those who made it involuntarily (Van Solinge \& Henkens, 2014; Fernández, Alcover \& Crego, 2013). In the sample of Spanish retirees, the first two clusters contain retirees who retired as a result of an involuntary process and the third and fourth clusters as a consequence of a voluntary process. A summary is presented in the following table (Table 3).

Table 3. Summary profiles found in Spanish retirement

\begin{tabular}{|c|c|c|c|c|}
\hline & \multicolumn{2}{|c|}{ INVOLUNTARY } & \multicolumn{2}{|c|}{ VOLUNTARY } \\
\hline & $\begin{array}{c}\text { GROUP 1 } \\
\text { Involuntary retirees }\end{array}$ & $\begin{array}{c}\text { GROUP 2 } \\
\text { Non-voluntary } \\
\text { retirees with high } \\
\text { resilience }\end{array}$ & $\begin{array}{c}\text { GROUP } 3 \\
\text { Voluntary with high } \\
\text { education and high } \\
\text { perceived social } \\
\text { support from friends }\end{array}$ & $\begin{array}{c}\text { GROUP 4 } \\
\text { Voluntary retirees } \\
\text { with low level of } \\
\text { education and high } \\
\text { satisfaction with } \\
\text { their family } \\
\end{array}$ \\
\hline \multirow{4}{*}{$\begin{array}{l}\text { Continuous } \\
\text { variables }\end{array}$} & \multirow{2}{*}{$\begin{array}{l}\text { High organizational } \\
\text { pressures }\end{array}$} & $\begin{array}{c}\text { High organizational } \\
\text { pressures }\end{array}$ & \multirow{2}{*}{$\begin{array}{l}\text { Low Organizational } \\
\text { pressures } \\
\text { High interest in } \\
\text { retirement }\end{array}$} & \multirow[t]{4}{*}{$\begin{array}{c}\text { Health problems } \\
\text { nonexistent }\end{array}$} \\
\hline & & $\begin{array}{l}\text { Low interest in } \\
\text { retirement }\end{array}$ & & \\
\hline & & Low stress levels & Perceived social & \\
\hline & Health problems & High resilience & support: friends & \\
\hline \multirow{3}{*}{$\begin{array}{l}\text { Categorical } \\
\text { variables }\end{array}$} & $\begin{array}{l}\text { Educational attainment } \\
\text { (without any formal } \\
\text { oducation) }\end{array}$ & $\begin{array}{l}\text { Private sector } \\
\text { workers }\end{array}$ & $\begin{array}{c}\text { Educational } \\
\text { attainment (university } \\
\text { qualifications) }\end{array}$ & $\begin{array}{c}\text { Educational } \\
\text { attainment (primary } \\
\text { level) }\end{array}$ \\
\hline & \multirow{2}{*}{$\begin{array}{l}\text { Occupational category } \\
\text { (administratives and } \\
\text { middle managers) }\end{array}$} & $\begin{array}{l}\text { Occupational } \\
\text { category (skilled and } \\
\text { unskilled workers) }\end{array}$ & Gender, women & Public sector \\
\hline & & Marital status, single & Marital status, married & $\begin{array}{l}\text { Marital status, single } \\
\text { or divorced }\end{array}$ \\
\hline
\end{tabular}

Consequently, it becomes evident that retired workers who wish to accept the offer of retirement are characterized by having strong personal interests in post-working life. This finding is consistent with those from some studies regarding retirement which indicate that the retirement decision involves the individual's preferences with regards to leisure and free-time activities, which they could pursue more easily in retirement than while continuing to work (Van Solinge \& Henkens, 2014).

With regard to the sociodemographic variables which have distinguished the clusters, some studies have made it clear that said variables condition the retirement experience and subsequent adaptation to retirement (Potocnik, Tordera \& Peiró, 2010). This study demonstrates that gender, occupational sector, level of educational attainment and marital status are significant variables when attempting to define groups of retirees with homogeneous characteristics. With regard to occupational category, various 
institutions have suggested that unskilled workers experience more health problems and organizational pressures than skilled workers. Skilled workers also demonstrate greater satisfaction during retirement as well as more freedom and control of their activities (Lund \& Villadsen, 2005)

This study has various limitations. Firstly, due to generational effects, the sample contained a lower number of retired women than men, which could skew the results as a consequence of differences in the perception of retirement by both genders. However, on the other hand, the sample is representative of the retired population in this age group in which men are overrepresented. Secondly, when analyzing the possible clusters, the variable time in retirement was not taken into consideration. The experience of retirement can be evaluated in different ways according to the time which has passed since the worker leaves employment. In this sense, the results may vary depending on whether the worker has been retired a short time and is in an initial or post-vacation phase or, on the contrary, they are in a period of disenchantment or acceptance (Gómez \& Martí, 2003). Thirdly, the high number of cases excluded due to the statistical procedure may have restricted the number of clusters resulting from the analysis. Finally, some factors in the reasons for retirement subscale present low internal consistency (organizational pressure $a=.48$ and work-related stress $a=.65$ ), which limit the findings and suggests the need for new factorial analyses in other large samples which are representative of Spanish retirees to improve the internal consistency of said subscale and its adaptation to the specific process of early retirement (Fernández, Crego \& Alcocer, 2011).

\section{Conclusions}

From the data analysis and discussion, we can conclude that there are four differentiated psychosocial profiles in our sample of Spanish retirees. Initially, voluntary and involuntary retirees can be grouped, depending on the way the retiree left the workforce. It is logical to suggest that groups one and two, those who could not choose the moment of their retirement, will need greater advice regarding the retirement process due specifically to this retirement variable. Thanks to the cluster analysis with groupings of continuous variables (organizational pressure, health problems, interest in retiring, work-related stress, resilience, perceived social support from friends, and satisfaction with family matters) and categorical variables (level of educational attainment, profession, occupational sector, marital status and gender), we were able to define distinct profiles for Spanish retirees.

In conclusion, this study represents a first step toward classifying the wide variety of experiences of transition to retirement and post-work adjustment, which are part of a phenomenon which affects a highly heterogeneous group of workers. This study also 
enables, for each retiree profile, the design of specific programs to re-organize leisure time, redefine personal identity or strategies to maintain and improve interpersonal and family relationships, both quantitatively and qualitatively, which in turn will influence health and longevity. Consequently, these programs would improve retirees' adaptation during retirement and their quality of life during this period, which would impact on a priority area in Spain and Europe, namely research into and the promotion of successful aging, particularly through preventative interventions.

\section{References}

Atchley, R.C. (1989). A continuity theory of normal aging. The Gerontologist, 29, 183- 190.

Beehr, T.A. (1986). The process of retirement: A review and recommendations for future investigation. Personnel Psychology, 39, 31-55.

Cadenas-Salazar, R., Villarreal-Ríos, E., Vargas-Daza, ER., Martínez-González, L., \& Galicia-Rodríguez. (2009). Relationship between functional social support and vital satisfaction in the elderly. Revista Médica del Instituto Mexicano del Seguro Social, 47(3), 311-314.

Dorn, D., \& Sousa-Poza, A. (2005). The determinants of early retirement in Switzerland. Swiss Journal of Economics and Statistics, 141(2), 247-283.

Fernández, J. J., Crego, A. y Alcover, C. M. (2011). La transición hacia el retiro: adaptación en una muestra de prejubilados españoles de la escala Retirement Satisfaction Inventory. Revista Española de Geriatría y Gerontología, 46, 139- 146.

Fernández, J.J., Alcover de la Hera, C. M., \& Crego, A. (2013). Psychosocial profiles of early retirees on the basis of their experiences during the transition to post-working life and adjustment to retirement. Revista de Psicología Social, 28(1), 99-113.

Floyd, F.J., Haynes, S.N., Rogers, E.D., Winemiller, D., Lemsky, C., Murphy, T.B., Werle, M., Heilman, N. (1992). Assessing retirement satisfaction and perceptions of retirement experiences. Psychology and Aging, 7(4), 609- 621.

Gómez, S. y Martí, C. (2003). Las prejubilaciones y su impacto en la persona en la empresa y en el sistema de pensiones. Universidad de Navarra, IESE Business School, Documento de Investigación № 522. IESE Business School - Cátedra SEAT de Relaciones Laborales: Madrid. Available online at http://www.iese.edu/research/pdfs/DI-0522.pdf [accessed 20 th June 2016]

Gore, S. (1978). The effect of social support in moderating the health consequences of unemployment. Journal of Health and Social Behavior, 19, 157- 165.

Guarino, L., \& Sojo, V. (2011). Apoyo social como moderador del estrés en la salud de los desempleados. Universitas Psychologica, 10(3), 867-879.

Kanfer, R., \& Ackerman, P.L. (2004). Aging, Adult Development and Work motivation. The Academy of Management Review, 29(3), 440- 458. 
Levy, B.R., Slade, M.D., \& Kasl, S.V. (2002). Longitudinal benefit of positive self-perceptions of aging on functional health. The Journals of Gerontology Series B: Psychological Sciences and Social Sciences, 57(5), 409-417.

Lund, T., \& Villadsen, E. (2005). Who retires early and why? Determinants of early retirement among Danish employees 57-62 years. European Journal of Ageing, 4, 275-280.

Moret-Tatay, C., Fernández, J.J., Navarro-Pardo, E., Civera, C, \& Alcover de la Hera, C. (2015). Psychometric properties and Factor structure of the BRCS in an elderly Spanish sample. Anales de Psicología, 31(3), 1030-1034.

Ong, A.D., Bergeman, C.S., Bisconti, T.L., \& Wallace, K.A. (2006). Psychological resilience, positive emotions, and successful adaptation to stress in later life. Journal of Personality and Social Psychology, 91, 730-749.

Potocnik, K., Tordera, N., \& Peiró, J.M. (2010). The influence of the early retirement process on satisfaction with early retirement and psychological well-being. International Journal of Aging \& Human Development, 70(3), 251-273.

Principi, A., Fabbietti, P., \& Lamura, G. (2015). Perceived qualities of older workers and age management in companies: Does the age of HR managers matter? Personnel Review, 44(5), 801-820.

Sinclair, V., \& Wallston, K. (2004). The development and Psychometric evaluation of the Brief Resilient Coping Scale. Assessment, 11(1), 94-101.

Solem, P. E., Syse, A., Furunes, T., Mykletun, R. J., De Lange, A.N., Schaufeli, W., \& Ilmarinen, J. (2014). To leave or not to leave: Retirement intentions and retirement behaviour. Ageing and Society, doi: 10.1017/S0144686X14001135.

Van der Heijden, B. I., Schalk, R., \& Van Veldhoven, M. J. (2008). Ageing and careers: European research on long-term career development and early retirement. Career Development International, 13(2), 85-94.

Van Droogenbroeck, F., \& Spruyt, B. (2014). To stop or not to stop: An empirical assessment of the determinants of early retirement among active and retired senior teachers. Research on Aging, 36(6), 753-777.

Van Solinge, H., \& Henkens, K. (2007). Involuntary retirement: the role of restrictive circumstances, timing, and social embeddedness. Journal of Gerontology, 62(5), 295-303.

Van Solinge, H., \& Henkens, K. (2014). Work-related factors as predictors in the retirement decisionmaking process of older workers in the Netherlands. Ageing and Society, 34(9), 1551- 1574.

Wang, M. (2007). Profiling Retirees in the Retirement Transition and Adjustment Process: Examining the Longitudinal Change Patterns of Retires Psychological Well-Being. Journal of Applied Psychology, 92(2), 455-474.

Zimet, G.D., Dahlem, N.W., Zimet, S.G., \& Farley, G.K. (1988). The Multidimensional Scale of Perceived Social Support. Journal of Personality Assessment, 52(1), 30-41. 
Yolanda López-Ramos

Department of Developmental and Educational Psychology. Universitat de València. Av. Blasco Ibáñez, 21. 46010, Valencia, Spain.

Esperanza Navarro-Pardo

Department of Developmental and Educational Psychology. Universitat de València. Av. Blasco Ibáñez, 21. 46010, Valencia, Spain.

Email: esperanza.navarro@uv.es

Juan José Fernández Muñoz

Department of Medicine and Surgery, Psychology, Preventive Medicine and Public Health and Medical Microbiology Immunology and Nursing and

Dentistry. Universidad.

Ricardo Pocinho

Investigador do grupo INTERTECH-Valencia. Doutor em Educação pela Universidad de Salamanca e Doutor em Psicogerontologia pela Universidad de Valencia. Director de pós-graduação e formador na área do Envelhecimento. Reitor da Universidade Sénior do Mondego

Correspondência

Esperanza Navarro-Pardo

Department of Developmental and Educational Psychology. Universitat de València. Av. Blasco Ibáñez, 21. 46010, Valencia, Spain.

Data de submissão: Novembro 2016

Data de avaliação: Fevereiro 2017

Data de publicação: Dezembro 2017 